\title{
IMPLEMENTASI DAN KENDALA SISTEM AKUNTANSI PEMERINTAH DAERAH BERBASIS AKRUAL
}

Writer:

Risnaningsih

Correspondence: ningsihrisna@yahoo.com

Institution:

Universitas Tribhuwana

Tunggadewi Malang

EKSIS

Vol XI No 2, 2016

ISSN:

$1907-7513$

http://ejournal.stiedewantara.ac.id/

\begin{abstract}
Hidayatullah (2010) said that the adoption of the accrual system not only aims to standards and formats mere presentation of financial statements, but also have an impact on changing the system of budgeting. In addition, the adoption of accrual accounting system will inevitably affect the performance measurement system and government. In other words, akrualisasi government accounting system in addition to changing the format of financial accountability, will also have an impact on fiscal policy and the government's performance in the future.

Each country is also experiencing different obstacles in the application of the accrual basis. Obstacles faced by local governments in the implementation of Government Accounting System accrual (Aaron, 2009: 131) including: preparation of standards that are not independent, the laws are conflicting, the lack of political support government elite, the lack of response from the House of Representatives, the lack of staff quality, constraints accounting reform at the local government level.
\end{abstract}

Keywords: Accounting Systems, Accrual, Government Performance

\section{abstrak}

Hidayatullah (2010) mengatakan pengadopsian sistem akrual tidak hanya bertujuan standar dan format penyajian laporan keuangan belaka, tetapi juga berdampak pada berubahnya sistem penyusunan anggaran. Di samping itu, pengadopsian sistem akuntansi akrual mau tidak mau akan mempengaruhi sistem dan pengukuran kinerja pemerintah. Dengan kata lain, akrualisasi sistem akuntansi pemerintahan selain merubah format akuntabilitas keuangan, juga akan berdampak pada kebijakan fiskal dan kinerja pemerintah di masa yang akan datang.

Setiap negara juga mengalami kendala yang berbeda-beda dalam penerapan basis akrual. Kendala yang dihadapi oleh Pemerintah Daerah dalam penerapan Sistem Akuntansi Pemerintah berbasis akrual (Harun, 2009:131) diantaranya: penyusunan standar yang tidak independen, produk hukum yang saling bertentangan, minimnya dukungan politik elit pemerintah, kurangnya respon dari Dewan Perwakilan Rakyat dan masyarakat, kurangnya staf yang berkualitas, kendala reformasi akuntansi pada tingkat pemerintah daerah.

Kata Kunci: Sistem Akuntansi, Akrual, Kinerja Pemerintah 


\section{A. PENDAhULUAN}

Akuntabilitas sektor publik saat ini telah mendapatkan banyak perhatian seiring dengan adanya pelaksanaan otonomi daerah. Otonomi daerah memberikan kewenangan kepada pemerintah daerah untuk mengatur rumah tangganya sendiri dengan meminimalkan campur tangan dari pemerintah pusat serta memiliki hak dan kewajiban untuk menggunakan sumbersumber keuangan yang dimiliki sesuai dengan kebutuhan masyarakat yang berkembang di daerah.

Untuk mendukung pelaksanaan otonomi daerah tersebut pemerintah telah mengeluarkan berbagai peraturan perundang-undangan yang telah mengalami banyak pembaharuan, diantaranya UU No. 17 Tahun 2003 tentang Keuangan Negara, UU No. 12 Tahun 2008 tentang Pemerintahan Daerah, UU No. 33 Tahun 2004 tentang Perimbangan Keuangan antara Pemerintah Pusat dan Daerah, serta PP No. 71 Tahun 2010 yang pada dasarnya pemerintah menyusun Sistem Akuntansi Pemerintahan yang mengacu pada Standar Akuntansi Pemerintahan berbasis akrual. Dalam Standar Akuntansi Pemerintahan Berbasis Akrual yang diakui adalah pendapatan, beban, aset, utang, dan ekuitas dalam pelaporan, serta pendapatan, belanja, dan pembiayaan dalam pelaporan pelaksanaan anggaran diakui berdasarkan basis yang ditetapkan dalam APBN/APBD.

Sebelum adanya peraturan pemerintah mengenai sistem akuntansi keuangan daerah berbasis akrual (basis accrual), sistem yang digunakan adalah sistem akuntansi tata buku tunggal (single entry accounting system) berbasis kas (basis cash). Sistem pencatatan single entry ini sangat sederhana yaitu hanya mencatat satu kali setiap terjadi transaksi. Transaksi yang menyebabkan kas bertambah akan dicatat di sisi penerimaan dan yang menyebabkan kas berkurang akan dicatat di sisi pengeluaran. Sistem pencatatan single entry sangat sederhana dan mudah dipahami, namun disamping itu juga mempunyai banyak kelemahan.

Menurut Bastian (2003:3), sistem akuntansi yang berbasis kas memiliki kelemahan sebagai berikut: (a) informasi yang lebih kompleks yang sebenarnya dibutuhkan oleh pemakai laporan keuangan tidak dapat disediakan oleh sistem akuntansi berbasis kas; (b) relevansi laporan keuangan bagi para pengambil keputusan sangat kurang, karena basis kas hanya berfokus pada aliran kas dan mengabaikan aliran sumber daya lain. (c) pertanggungjawaban ke publik terbatas pada penggunaan kas saja, tidak dicantumkan pertanggungjawaban atas pengelolaan aktiva lainnya dan utang atau kewajiban.

Banyaknya kekurangan dari single step berbasis kas tersebut menuntut pemerintah untuk memperbaiki sistem akuntansi keuangan pemerintah daerah. Maka sistem yang lama dikembangkan menjadi sistem baru yang dapat mempermudah dalam penyusunan laporan keuangan daerah berupa Laporan Pelaksanaan Anggaran (budgetary reports) yang terdiri dari Laporan Realisasi Anggaran (LRA), Laporan Perubahan Sisa Anggaran Lebih (SAL), Laporan Keuangan (financial reports) yang terdiri dari Neraca, Laporan Operasi (LO), Laporan Perubahan Ekuitas (LPE), dan Laporan Arus Kas (LAK) serta Catatan Atas Laporan Keuangan (CaLK).

Karakter dalam sistem yang baru adalah double entry dan basis akrual (accrual basis). Sistem tersebut dapat memberikan informasi kepada pemakai laporan keuangan tidak hanya dari transaksi masa lalu yang berkaitan dengan penerimaan dan pengeluaran kas tetapi juga kewajiban kas yang timbul di 
masa depan serta peramalan kas yang akan diterima di masa mendatang. Ngumar (2001:149) mengungkapkan keberpihakannya pada basis akrual dengan menyatakan bahwa umumnya sistem pencatatan berbasis akrual lebih akuntabel daripada sistem yang berbasis kas, karena dengan menggunakan basis akrual akan didapatkan informasi tentang dana secara wajar pada akhir periode, apalagi tahun anggaran sudah dipergunakan tahun takwim sehingga dapat dimatch dan dicut-off hak dan kewajiban pemerintah daerah pada akhir periode akuntansi.

Dasar akuntansi yang memenuhi tuntutan tentang laporan keuangan adalah basis akrual. Akan tetapi, karena penerapan basis akrual secara sepenuhnya pada sistem akuntansi keuangan daerah memerlukan banyak perubahan pada sumber daya manusia dan teknologi, maka penerapan basis akrual dilakukan secara bertahap melalui suatu proses transisi (Halim, 2002:40). Setiap perubahan dan pergantian akan selalu membawa dampak positif atau negatif sekecil apapun. Dengan perubahan sistem akuntansi keuangan daerah dari sistem sebelumnya yang telah mengakar dan membudaya (single entry berbasis kas menjadi double entry berbasis akrual) tentu akan membawa suatu permasalahan tersendiri. Hidayatullah (2010) mengatakan pengadopsian sistem akrual tidak hanya bertujuan standar dan format penyajian laporan keuangan belaka. tetapi juga berdampak pada berubahnya sistem penyusunan anggaran. Di samping itu, pengadopsian sistem akuntansi akrual mau tidak mau akan mempengaruhi sistem dan pengukuran kinerja pemerintah. Dengan kata lain, akrualisasi sistem akuntansi pemerintahan selain merubah format akuntabilitas keuangan, juga akan berdampak pada kebijakan fiskal dan kinerja pemerintah Indonesia di masa yang akan datang.

Namun kenyataannya penerapan sistem akuntansi berbasis akrual tersebut menjadi kendala bagi pemerintah Indonesia. Menurut Halim (2012) apabila pemerintah menerapkan sistem akuntansi berbasis akrual, maka seharusnya akuntansi anggarannya juga berbasis akrual. Hal inilah yang menjadi tanda tanya bagi masyarakat tentang sistem akuntansi berbasis akrual yang dijalankan pemerintah saat ini.

\section{B. PEMBAHASAN \\ Standar Akuntansi Pemerintah}

Menurut Ritonga (2004) Standar akuntansi merupakan pedoman atau prinsip-prinsip yang mengatur perlakuan akuntansi dalam penyusunan laporan keuangan untuk tujuan pelaporan kepada para pengguna laporan keuangan. Menurut Pasal 1 ayat 3 PP No.71 Tahun 2010 SAP adalah prinsip-prinsip akuntansi yang diterapkan dalam menyusun dan menyajikan laporan keuangan pemerintah. PP No.71 Tahun 2010 tentang Standar Akuntansi Pemerintah terbit pada tanggal 22 Oktober 2010. SAP disusun oleh Komite Standar Akuntansi Pemerintah (KSAP).

Berdasarkan pengertian Standar Akuntansi Pemerintah (SAP) menurut PP No.71 Tahun 2010, SAP dibutuhkan dalam rangka penyusunan laporan keuangan meliputi Laporan Realisasi Anggaran (LRA), Laporan Perubahan Saldo Anggaran Lebih ( Laporan Perubahan SAL), Neraca, Laporan Operasional (LO), Laporan Arus Kas (LAK), Laporan Perubahan Entitas (LPE), serta Catatan atas Laporan Keuangan (CaLK). Sesuai dengan SAP Pasal 7, penerapan SAP Berbasis Akrual dapat dilaksanakan secara bertahap dari penerapan SAP Berbasis Kas Menuju Akrual menjadi penerapan SAP Berbasis 
Kas. SAP Berbasis Kas Menuju Akrual pada Lampiran II berlaku selama masa transisi bagi entitas yang belum siap untuk menerapkan SAP Berbasis Akrual sedangkan untuk SAP Berbasis Akrual terdapat pada Lampiran I dan berlaku sejak tanggal ditetapkan dan dapat segera diterapkan oleh setiap entitas.

\section{Tabel 1: Perbedaan Basis Kas dan Basis Akrual}

\begin{tabular}{|c|c|c|}
\hline & Basis Kas & Basis Akrual \\
\hline $\begin{array}{l}\text { Komponen Laporan } \\
\text { Keuangan }\end{array}$ & $\begin{array}{l}\text { 1. Laporan Realisasi Anggaran } \\
\text { (LRA) } \\
\text { 2. Neraca } \\
\text { 3. Laporan Arus Kas (LAK) } \\
\text { 4. Catatan atas Laporan Keuangan } \\
\text { (CaLK) }\end{array}$ & $\begin{array}{l}\text { 1. Laporan Realisasi Anggaran } \\
\text { (LRA) } \\
\text { 2. Laporan Perubahan Saldo } \\
\text { Anggaran Lebih } \\
\text { 3. Neraca } \\
\text { 4. Laporan Operasional (LO) } \\
\text { 5. Laporan Arus Kas (LAK) } \\
\text { 6. Laporan Perubahan Ekuitas (LPE) } \\
\text { 7. Catatan atas Laporan Keuangan } \\
\text { (CaLK) }\end{array}$ \\
\hline $\begin{array}{l}\text { Pengakuan } \\
\text { Pendapatan }\end{array}$ & $\begin{array}{l}\text { Pengakuan pendapatan pada basis kas } \\
\text { adalah pada saat penerimaan } \\
\text { pembayaran secara kas. Dalam } \\
\text { konsep saat pengakuan pendapatan } \\
\text { pada basis akrual adalah pada saat } \\
\text { mempunyai hak untuk melakukan } \\
\text { penagihan dari cash basis menjadi hal } \\
\text { yang kurang penting mengenai kapan } \\
\text { munculnya hak untuk menagih. } \\
\text { Makanya dalam cash basis kemudian } \\
\text { muncul adanya metode penghapusan } \\
\text { piutang secara langsung dan } \\
\text { tidak mengenal adanya } \\
\text { estimasi piutang tak tertagih } \\
\text { (Ritonga, 2004:3). }\end{array}$ & $\begin{array}{l}\text { Saat pengakuan pendapatan pada } \\
\text { basis akrual adalah pada saat } \\
\text { mempunyai hak untuk melakukan } \\
\text { penagihan dari hasil kegiatan. Dalam } \\
\text { konsep basis akrual menjadi hal yang } \\
\text { kurang penting mengenai kapan kas } \\
\text { benar-benar diterima. Maka dalam } \\
\text { basis akrual kemudian } \\
\text { muncul adanya estimasi piutang tak } \\
\text { tertagih, sebab penghasilan sudah } \\
\text { diakui padahal kas belum diterima } \\
\text { (Ritonga, 2004:3). }\end{array}$ \\
\hline Pengakuan Biaya & $\begin{array}{l}\text { Pengakuan biaya dilakukan pada saat } \\
\text { sudah dilakukan pembayaran secara } \\
\text { kas. } \\
\text { Sehingga dengan kata lain, pada saat } \\
\text { pembayaran sudah diserahkan maka } \\
\text { biaya sudah diakui pada saat itu juga } \\
\text { (Ritonga, 2004:3). }\end{array}$ & $\begin{array}{l}\text { Pengakuan biaya dilakukan } \\
\text { pada saat kewajiban membayar sudah } \\
\text { terjadi. Sehingga dengan kata lain, } \\
\text { pada saat kewajiban membayar sudah } \\
\text { terjadi, maka titik ini dapat dianggap } \\
\text { sebagai awal } \\
\text { munculnya biaya meskipun biaya } \\
\text { tersebut belum dibayar. Dalam era } \\
\text { bisnis } \\
\text { dewasa ini, perusahaan selalu dituntut } \\
\text { untuk senantiasa menggunakan } \\
\text { konsep basis akrual } \\
\text { (Ritonga, 2004:3). }\end{array}$ \\
\hline
\end{tabular}

\section{Strategi Persiapan Penerapan Basis Akrual}

Untuk persiapan penerapan basis akrual secara penuh tentu pemerintah memerlukan strategi. Medina (2011) menyatakan prasyarat pelaksanaan strategi terbagi atas dua kondisi dasar, yaitu necessary condition dan sufficient condition. Necessary condition merupakan prasyarat yang dibutuhkan agar suatu kondisi dapat tercapai. Kemudian pemerintah dapat mengembangkan beberapa hal yang menjadikan kondisinya berubah menjadi kondisi yang mencukupi (sufficient condition). Necessary condition adalah komitmen, kapasitas SDM, dan dana pemeliharaan.

Penerapan basis akrual dibutuhkan komitmen dari para pemimpin dan 
pejabat termasuk dukungan politik dari Kepala Daerah dan DPRD. Komitmen adalah sikap kesediaan diri untuk memegang teguh visi, misi serta kemauan untuk mengerahkan seluruh usaha dalam melaksanakan tugas (Robbins, 2002:284). Dukungan yang kuat dari pimpinan merupakan kunci keberhasilan dari suatu perubahan. Kemudian SDM yang menguasai ilmu dan konsep akuntansi dalam jumlah yang memadai juga dibutuhkan.

Masa awal penerapan akuntansi pemerintahan memerlukan SDM yang menguasai akuntansi pemerintahan, untuk itu pemerintah perlu secara serius menyusun perencanaan SDM di bidang akuntansi pemerintahan. Penerapan basis akrual juga membutuhkan pendanaan yang cukup untuk investasi awal dan untuk kegiatan-kegiatan yang bersifat pemeliharaan. Hal ini disebabkan penerapan basis akrual membutuhkan pembaharuan yang terus menerus, sehingga tersedianya dana pemeliharaan pun sangat dibutuhkan. Persyaratan tambahan untuk mengubah kondisi menjadi sufficient condition adalah kebijakan akuntansi, prosedur, dan teknologi.

Pengembangan dokumen kebijakan akuntansi berbasis akrual didesain sedemikian rupa sesuai dengan kondisi khas di daerah masing-masing. Kemudian, dibutuhkan pula sistem dan prosedur yang menjelaskan teknik-teknik pencatatan, penyiapan dokumen, sampai dengan penyusunan laporan keuangan dengan basis akrual penuh. Pemerintah daerah juga memerlukan dukungan teknologi, khususnya aplikasi penatausahaan \& akuntansi yang mengakomodasi basis akrual didalamnya agar penerapan basis akrual ini dapat sesuai harapan (Medina, 2011).

\section{Pelaksanaan Basis Akrual}

Negara yang pertama kali menggunakan laporan keuangan dan anggaran berbasis akrual adalah New Zealand. Kemudian diikuti oleh negaranegara lain seperti USA serta Australia pada tahun 1997. Pada era 2000, langkah ini diikuti oleh hampir 22 negara dari 30 negara anggota OECD (Organization for Economic Cooperation and Development), kemudian disusul oleh Malaysia dan Tanzania, pada tahun 2001 oleh Inggris dan Kanada, tahun 2003 oleh Afrika Selatan dan di tahun 2005 oleh negara-negara anggota Uni Eropa. Sedangkan negara-negara yang masih dalam proses untuk pindah ke akuntansi akrual adalah Perancis, Kepulauan Fiji, Indonesia, Republik Rakyat Cina, Filipina, Republik Korea, Sri Lanka, serta Mongolia. Penerapan basis akuntansi di negara-negara di dunia memang bervariasi, tetapi yang terpenting adalah manfaat akuntansi sendiri, yaitu untuk memberikan informasi yang relevan bagi para pemangku kepentingan (Medina, 2011).

$\begin{array}{rrr}\text { Akuntansi } & \text { akrual dipandang } \\ \text { sangat populer } & \text { dalam perjalanan } \\ \text { reformasi sektor publik, usaha ini }\end{array}$ memerlukan kesiapan tenaga kerja yang lebih terampil dalam tata buku pemerintahan (Harun, 2009:14). Namun, masih terdapat kritik yang mengatakan bahwa akuntansi akrual lebih cocok untuk dunia usaha karena sektor publik lebih berorientasi pada pelayanan daripada mencari laba. Penerapan akuntansi akrual merupakan suatu teknologi informasi untuk menciptakan transparansi yang lebih besar atas aktivitas sektor publik yang akhirnya bertujuan meningkatkan akuntabilitas pemerintahan serta memperbaiki kualitas pengambilan keputusan. Salah satu kekurangan paling mendasar negaranegara berkembang dalam upaya mereka menciptakan akuntabilitas yang lebih besar atas penggunaan aset publik adalah kelemahan yang akut dalam sistem 
akuntansi dan manajemen keuangan negara (Harun, 2009:39).

Faktor yang juga berpengaruh dalam keberhasilan perubahan akuntansi pemerintah adalah ada tidaknya dukungan dari karakteristik lingkungan sosial pemerintah, karakterisitik sistem politik dan administrasi pemerintah yang kondusif, serta seberapa serius kendala yang dihadapi (Harun, 2009:120).

Sedangkan menurut Christensen (2002), keberhasilan adopsi akuntansi akrual untuk sektor publik tergantung pada hadirnya stimuli yang mendorong terjadinya reformasi, interaksi positif antara promotor inovasi akuntansi pemerintahan dan ada tidaknya kendala yang secara potensial menghalangi kesuksesan reformasi. Selain itu setiap negara juga mengalami kendala yang berbeda-beda dalam penerapan basis akrual. Kendala yang dihadapi oleh Pemerintah Daerah dalam penerapan Sistem Akuntansi Pemerintah berbasis akrual (Harun, 2009:131) diantaranya:

1. Penyusunan standar yang tidak independen

2. Produk hukum yang saling bertentangan

3. Minimnya dukungan politik elit pemerintah

4. Kurangnya respon dari DPR dan masyarakat

5. Kurangnya staf yang berkualitas

6. Kendala reformasi akuntansi pada tingkat pemerintah daerah

Menurut Wansur (2011) kendala yang dihadapi dalam penerapan sistem akuntansi berbasis akrual, diantaranya:

1. Kualitas sumber daya manusia yang belum memadai

Persoalan ini sangat mendasar mengingat mekanisme perekrutan PNS yang masih terpusat, meskipun kewenangan untuk pelaksanaan program peningkatan kualitas SDM ada di pemerintah daerah. Apalagi dengan adanya pemekaran daerah, hal ini menjadi persoalan tersendiri ketika SDM yang terbatas kemudian harus dibagi lagi.

2. Struktur organisasi

Sesuai Peraturan Pemerintah Nomor 41 Tahun 2007, Pemerintah Daerah harus menyusun struktur organisasi baru dimana ruang untuk akuntansi semakin terbuka. Namun, rendahnya kualitas dan kuantitas SDM akuntansi menjadi persoalan yang semakin berat.

3. Aspek regulasi

Ketidakkonsistenan dalam penerbitan peraturan perundangan terkait akuntansi pemerintahan mengakibatkan Pemerintah Daerah kurang serius untuk melaksanakan akuntansi. Pemerintah Daerah merasa dijadikan objek karena beberapa petunjuk teknis atau pedoman pelaksanaan tidak sejalan.

4. Aspek sosialisasi dan pendampingan Sosialisasi oleh Kementerian Dalam Negeri, Komite Standar Akuntansi Pemerintah, Badan Pemeriksa Keuangan dan pihak-pihak lain telah berjalan, tetapi masih sangat kurang. Hal tersebut dapat disebabkan oleh beberapa faktor antara lain masalah pendanaan serta wilayah dengan akses transportasi yang cukup sulit seperti wilayah-wilayah di pedalaman Kalimantan atau Papua.

5. Pemberian sanksi

Sampai dengan saat ini tidak ada sanksi yang diberikan kepada Pemerintah Daerah apabila tidak melaksanakan Sistem Akuntansi Pemerintah. Opini Badan Pemeriksa Keuangan berupa "Tidak Wajar" atau "Disclaimer" hanya sekedar opini, tidak ada akibat hukum apapun. Dengan tidak adanya sanksi yang tegas maka dapat mengakibatkan pelaksanaan yang tidak serius.

6. Kemauan Politik
Pelaksanaan Sistem Akuntansi

Pemerintah sangat terkait dengan 
itikad pimpinan atau kemauan politik pemegang kekuasaan. Dengan diterapkannya sistem yang baik akan memperkecil ruang untuk melakukan penyimpangan, sehingga apabila tidak ada komitmen yang kuat dari pimpinan maka sistem tersebut tidak akan berjalan dengan baik.

\section{Implikasi Penerapan Basis Akrual}

Penerapan basis akrual pada akuntansi pemerintah seperti yang telah diuraikan diatas setidaknya mempunyai implikasi sebagai berikut:

1. Bahwa perubahan kebijakan akuntansi perlu dibuat secara reproaktif dengan menerbitkan kembali informasi keuangan yang terdahulu sebagai akibat dari perubahan-perubahan kebijakan akuntansinya.

2. Surplus anggaran, dengan demikian, adalah selisih antara pendapatan dan biaya (bukan belanja)

3. Akibat-akibat yang ditimbulkan dari kebijakan akuntansi memang harus direview oleh Badan Audit.

Dengan demikian, gambaran-gambaran arah masa depan dari akibat perubahan kebijakan akuntansi akan mencakup seperti tabel dibawah ini.

\section{Tabel 2. Akibat Perubahan Kebijakan Akuntansi}

\begin{tabular}{|l|c|c|}
\hline \multirow{2}{*}{\multicolumn{1}{c|}{ Accounting Policy Changes }} & \multicolumn{2}{c|}{ Impact of Change on } \\
\cline { 2 - 3 } & Net Debt & Accumulated Deficit \\
\hline Capital Assets & No change & Decrease \\
Tax Receivables & Decrease & Decrease \\
Tax Refunds Payable & Increase & Increase \\
Prepayments & No change & Decrease \\
Environmental Liabilities & Increase & Increase \\
Aboriginal Liabilities & Increase & Increase \\
\hline
\end{tabular}

\section{Usulan Implementasi Penerapan Sistem Akuntansi Pemerintah Daerah Berbasis Akrual}

Pada hakekatnya, ilmu akuntansi pemerintah yang mempunyai karakteristik yang berbeda dengan akuntansi bisnis, bukanlah ilmu yang mudah untuk dipahami oleh para penyusun laporan keuangan pemerintah, termasuk pegawai pemerintah sekalipun. Sistem akuntansi pemerintah yang nantinya akan menjabarkan standar akuntansi pemerintahan produk dari KSAP sudah selayaknya didesain sedemikan rupa agar simple to learn and operate dan easy to consolidate. Apakah desain sistem akuntansi pemerintah, khususnya pada pemerintah pusat, telah mudah dipelajari dan dioperasikan ataukah sistem tersebut memudahkan untuk pembuatan laporan konsolidasian?

Dari pengalaman memahami Sistem Akuntansi Pemerintah Pusat berdasarkan Peraturan Menteri Keuangan No 59 tahun 2005 yang kemudian diperbarui dengan Peraturan Menteri Keuangan No 171 tahun 2007, maupun Sistem Akuntansi Pemerintah Daerah seperti tercantum dalam Pedoman Pengelolaan Keuangan Daerah berdasar Permendagri No 13 tahun 2006 yang kemudian diperbarui dengan Permendagri No 59 tahun 2008, sebagian orang banyak mengalami kendala dalam menafsirkan pola kesisteman yang dikembangkan oleh pembuat peraturan.

Widjajarso (2011) akan mencoba memberikan usulan implementasi Standar Akuntansi Pemerintahan yang nantinya tertuang dalam sistem akuntansi pemerintah dengan pendekatan pemahaman umum insan akuntansi yang sudah terpola dengan kesisteman yang dikembangkan pada akuntansi bisnis atau komersial. Ada baiknya sub sistem dari sebuah sistem akuntansi pemerintah 
pusat dan daerah, didesain dengan menggabungkan pola sistem yang telah ada dengan pola sistem yang telah dikembangkan oleh sektor swasta hanya dengan satu target agar mudah dipahami.

Menurut Mulyadi (2005), sebuah sistem akuntansi terdiri dari sistem akuntansi pokok dan sistem akuntansi di luar sistem akuntansi pokok. Sistem akuntansi pokok mencakup formulir, jurnal dan buku besar. Dengan demikian, setiap sub sistem dari akuntansi pusat, mungkin Sistem Akuntansi Bendahara Umum dan Sistem Akuntansi Instansi termasuk segala sub sistem yang berkaitan harusnya disamakan persepsinya terlebih dahulu dalam hal formulir, jurnal dan buku besar. Dengan begitu, siapa pun pelaku sistem dan dimana pun bertugas dapat dengan mudah memahami konsep sistem tersebut.

Bukan hal mudah bagi pelaksana sistem di lingkungan pemerintah daerah untuk mencerna isi yang terkandung dalam Permendagri yang mengatur sistem akuntansi pemerintah. Ada kemungkinan penyusun Sistem Akuntansi Pemerintah Pusat dan penyusun Pedoman Pengelolaan Keuangan Pemerintah Daerah bisa jadi menafsirkan secara berbeda Standar Akuntansi Pemerintahan. Kemudian sistem di luar pokok dapat mencakup karena entitas pemerintah bergerak dalam sektor jasa sistem akuntansi pendapatan dan piutang, sistem akuntansi biaya dan hutang, sistem akuntansi penerimaan dan pengeluaran kas, sistem akuntansi persediaan, sistem akuntansi aktiva tetap, dan tentunya dapat ditambahkan sistem akuntansi belanja dan transfer. Hal yang ingin ditunjukkan oleh Widjajarso bukan pada jenis sub sistem yang ada, tetapi hanya meletakkan pola kesisteman yang identik dengan pola kesisteman pada entitas swasta, agar pemahaman atas standar dan implementasinya dilakukan dengan kerangka berpikir yang tidak jauh berbeda.

Akhirnya implementasi standar akuntansi pemerintahan mensyaratkan adanya sinkronisasi antara praktek akuntansi pada pemerintah pusat dan pemerintah daerah, mengingat acuan yang digunakan sama persis, yakni Standar Akuntansi Pemerintahan. Kedua penyusun sistem, Departemen Keuangan untuk pemerintah pusat dan Departemen Dalam Negeri untuk pemerintah daerah, haruslah memulai dengan langkahlangkah koordinasi dalam setiap proses pengembangan sistem, termasuk koordinasi dengan badan audit yakni Badan Pemeriksa Keuangan yang memang mempunyai wewenang untuk melaksanakan audit berdasar peraturan perundangan. Bila koordinasi dapat terjadi dengan efektif, Badan Pemeriksa Keuangan tidak akan mendapatkan laporan audit yang berbeda antara laporan keuangan pemerintah pusat dan pemerintah daerah, mengingat keduanya harus diberikan opini yang didasarkan pada standar akuntansi yang sama.

\section{PENUTUP}

Berdasarkan PP No. 71 Tahun 2010, pemerintah menyusun Sistem Akuntansi Pemerintahan yang mengacu pada Standar Akuntansi Pemerintahan berbasis akrual. Dalam Standar Akuntansi Pemerintahan berbasis akrual yang diakui adalah pendapatan, beban, aset, utang, dan ekuitas dalam pelaporan, serta pendapatan, belanja, dan pembiayaan dalam pelaporan pelaksanaan anggaran diakui berdasarkan basis yang ditetapkan dalam APBN/APBD.

Hidayatullah (2010) mengatakan pengadopsian sistem akrual tidak hanya bertujuan standar dan format penyajian laporan keuangan belaka. tetapi juga berdampak pada berubahnya sistem penyusunan anggaran. Di samping itu, 
pengadopsian sistem akuntansi akrual mau tidak mau akan mempengaruhi sistem dan pengukuran kinerja pemerintah. Dengan kata lain, akrualisasi sistem akuntansi pemerintahan selain merubah format akuntabilitas keuangan, juga akan berdampak pada kebijakan fiskal dan kinerja pemerintah Indonesia di masa yang akan datang.

Implementasi standar akuntansi pemerintahan mensyaratkan adanya sinkronisasi antara praktek akuntansi pada pemerintah pusat dan pemerintah daerah, mengingat acuan yang digunakan sama persis, yakni Standar Akuntansi Pemerintahan. Kedua penyusun sistem, Departemen Keuangan untuk pemerintah pusat dan Departemen Dalam Negeri untuk pemerintah daerah, haruslah memulai dengan langkah-langkah koordinasi dalam setiap proses pengembangan sistem, termasuk koordinasi dengan badan audit yakni Badan Pemeriksa Keuangan yang memang mempunyai wewenang untuk melaksanakan audit berdasar peraturan perundangan. Bila koordinasi dapat terjadi dengan efektif, Badan Pemeriksa Keuangan tidak akan mendapatkan laporan audit yang berbeda antara laporan keuangan pemerintah pusat dan pemerintah daerah, mengingat keduanya harus diberikan opini yang didasarkan pada standar akuntansi yang sama.

\section{DAFTAR PUSTAKA}

Arief, Hidayatullah. 2010. Standar Akuntansi Pemerintahan. http://ariefh. wordpress.com.

Bastian, Indra. 2003. Sistem Akuntansi Sektor Publik: Konsep Untuk Pemerintah Daerah. Salemba Empat. Jakarta.

Christensen, M. 2002. Accrual Accounting in The Public Sector: The Case of The New South Wales Government. Accounting History. November. Vol. 7.

Halim, Abdul. 2002. Akuntansi Sektor Publik Akuntansi Keuangan Daerah. Edisi Pertama. Salemba Empat. Jakarta.

Harun. 2009. Reformasi Akuntansi dan Manajemen Sektor Publik di Indonesia. Salemba empat. Jakarta.

IAI. 2004. Standar Akuntansi Keuangan. Salemba Empat. Jakarta.

Medina Consulting. 2011. Strategi Penerapan Basis Akrual Secara Penuh di Indonesia. http://medinamultimitra.com.

Ritonga, H Rahmansyah. 2004. Kas Basis Vs Akrual Basis. Widyaiswara BDK Medan. Medan.

Wansur. 2011. Tantangan Implementasi Akuntansi Berbasis Akrual dalam Sistem Akuntansi Pemerintahan. http://wansur.blogspot.com.

Widjajarso, Bambang. 2011. Penerapan Basis Akrual Pada Akuntansi Pemerintah Indonesia: Sebuah Kajian Pendahuluan. http://sutaryofe.staff.uns.ac.id/files/ 2011/10/Akuntansi-berbasisakrual.pdf. 